\title{
Ovarian follicular cells have innate immune capabilities that modulate their endocrine function
}

\author{
Shan Herath, Erin J Williams, Sonia T Lilly, Robert O Gilbert ${ }^{1}$, Hilary Dobson ${ }^{2}$, Clare E Bryant ${ }^{3}$ \\ and I Martin Sheldon \\ Department of Veterinary Clinical Sciences, Royal Veterinary College, University of London, Royal College Street, \\ London NW1 OTU, UK, ${ }^{1}$ College of Veterinary Medicine, Cornell University, Ithaca, New York 14853, USA, \\ ${ }^{2}$ Department of Veterinary Clinical Science and Animal Husbandry, University of Liverpool, Leahurst, Chester High \\ Road, Neston CH64 7TE, UK and ${ }^{3}$ Department of Clinical Veterinary Medicine, Centre for Veterinary Science, \\ University of Cambridge, Cambridge CB3 OES, UK
}

Correspondence should be addressed to I M Sheldon; Email: sheldon@rvc.ac.uk

S Herath and E J Williams contributed equally to this work

\begin{abstract}
Oestrogens are pivotal in ovarian follicular growth, development and function, with fundamental roles in steroidogenesis, nurturing the oocyte and ovulation. Infections with bacteria such as Escherichia coli cause infertility in mammals at least in part by perturbing ovarian follicle function, characterised by suppression of oestradiol production. Ovarian follicle granulosa cells produce oestradiol by aromatisation of androstenedione from the theca cells, under the regulation of gonadotrophins such as FSH. Many of the effects of $E$. coli are mediated by its surface molecule lipopolysaccharide (LPS) binding to the Toll-like receptor-4 (TLR4), CD14, MD-2 receptor complex on immune cells, but immune cells are not present inside ovarian follicles. The present study tested the hypothesis that granulosa cells express the TLR4 complex and LPS directly perturbs their secretion of oestradiol. Granulosa cells from recruited or dominant follicles are exposed to LPS in vivo and when they were cultured in the absence of immune cell contamination in vitro they produced less oestradiol when challenged with LPS, although theca cell androstenedione production was unchanged. The suppression of oestradiol production by LPS was associated with down-regulation of transcripts for aromatase in granulosa cells, and did not affect cell survival. Furthermore, these cells expressed TLR4, CD14 and MD-2 transcripts throughout the key stages of follicle growth and development. It appears that granulosa cells have an immune capability to detect bacterial infection, which perturbs follicle steroidogenesis, and this is a likely mechanism by which ovarian follicle growth and function is perturbed during bacterial infection.
\end{abstract}

Reproduction (2007) 134 683-693

\section{Introduction}

Oestrogens are intimately involved in the growth and development of ovarian follicles from the early antral stage to ovulation, with fundamental roles in steroidogenesis, nurturing the oocyte, ovulation and the subsequent formation of the corpus luteum (CL; Matzuk et al. 2002, Schams \& Berisha 2002). Oestradiol is produced by granulosa cell aromatisation of androgens secreted by the theca cells (Fortune 1994). Oestradiol synergises with the gonadotrophins to regulate the expression of follicle-stimulating hormone (FSH) and luteinising hormone (LH) receptors on granulosa cells, which are important developmental checkpoints in the lifespan of the follicle at recruitment and selection respectively (Dierich et al. 1998, Ma et al. 2004). Towards the end of the ovarian cycle, secretion of oestradiol by the dominant follicle stimulates the pituitary LH surge, which induces ovulation (Moenter et al. 1990). However, cattle that ovulate a smaller follicle with lower oestradiol concentrations form a smaller $\mathrm{CL}$ with lower peripheral plasma progesterone concentrations (Perry et al. 2005, Robinson et al. 2005). Progesterone is critical for implantation, and the recognition and maintenance of pregnancy (Spencer et al. 2004). Hence, perturbation of follicle growth and oestradiol production has important consequences for ovulation, conception and pregnancy.

Uterine bacterial infections are commonly acquired by humans and animals during coitus and after parturition. Each year 350 million new, mainly bacterial, sexually transmitted infections occur in adults of reproductive age (http://www.who.int/topics/sexually_transmitted_infections), the majority of which are initially asymptomatic, but the consequences range from subfertility to severe pelvic inflammatory disease 
(PID; Quayle 2002, Butler 2004). Mammalian fertility is also compromised by PID associated with post partum bacterial infections. Bos taurus is an economically important species, where considerable infertility is caused by bacterial contamination of the uterus, which is ubiquitous after parturition (Dohmen et al. 2000, Sheldon et al. 2002), with $40 \%$ of animals developing PID and infection persisting $>3$ weeks in $15 \%$ of cows as endometritis (Sheldon \& Dobson 2004). The gramnegative Eschericia coli is the first and the most common pathogenic bacteria isolated from the uterus (Dohmen et al. 2000, Sheldon et al. 2002); and lipopolysaccharide (LPS), the main pathogenic moiety of $E$. coli, is detectable in the plasma of cows with uterine infection (Mateus et al. 2003). Infertility is not only associated with uterine damage but also with perturbation of the ovarian cycle. Disease associated with E. coli or infusion of LPS suppresses oestradiol production and follicular growth in a range of mammals (Xiao et al. 1998, Battaglia et al. 2000, Sheldon et al. 2002). However, the availability of suitable tissue for research is a major constraint to advancing knowledge of the effects of bacterial infection on ovarian function in humans. Monovulatory domestic ruminants such as $B$. taurus represent a physiologically relevant model to study these basic mechanisms (Campbell et al. 2003). Furthermore, organisms infecting the uterus, such as Escherichia and Tritrichomonas species, are similar in humans and cattle (Sheldon et al. 2002, Kamiyama et al. 2004, Singh et al. 2004, Herath et al. 2006a), making the cow a good model for studying uterine disease and immunity.

The host response to infection depends on innate immunity in which intrinsic mechanisms are responsible for recognising and responding to pathogen challenge (Janeway et al. 2001). Toll-like receptors (TLRs), which are usually associated with professional immune cells, recognise pathogen-associated molecules (Beutler 2004, Akira et al. 2006) and engagement with TLRs initiates a signalling cascade that stimulates the production of immune mediators, which orchestrate the immune response (Akira \& Takeda 2004, Beutler 2004). However, the presence of physical barriers and the limitation of antigen at immune privileged sites raise the question whether cells in isolated areas express TLRs. Granulosa cells reside within the basement membrane of the ovarian follicle, separating them from the local vasculature and preventing immune cell transmigration (Petrovska et al. 1996). However, the basement membrane of the ovarian follicle is highly porous to molecules like LPS and the molecular mass cut-off is calculated to be 100-850 kDa (Rodgers et al. 1999). Since E. coli infection or LPS perturbs ovarian follicle development and suppresses oestradiol production in vivo, the present study tested the hypothesis that granulosa cells express the TLR4 complex and LPS directly perturbs their secretion of oestradiol.

\section{Results}

\section{Presence of LPS in ovarian follicular fluid}

The concentrations of LPS in follicular fluid collected from normal postpartum animals were below the limits of detection in 16 of 19 animals (mean $0.06 \pm 0.04 \mathrm{ng} / \mathrm{ml}$; range $0-0.8 \mathrm{ng} / \mathrm{ml}$ ). However, concentrations of LPS were higher in seven cows with clinical endometritis (mean $176.1 \pm 112 \mathrm{ng} / \mathrm{ml}, P<0.05$; range $4.3-875.2 \mathrm{ng} / \mathrm{ml}$ ). The follicular fluid concentrations in animals with subclinical endometritis were intermediate between the normal and clinical cases, with 4 of 8 cows below the limit of detection for mild cases (mean $0.7 \pm 0.3 \mathrm{ng} / \mathrm{ml}$; range $0-0.8 \mathrm{ng} / \mathrm{ml}$ ) and 8 of 24 cows below the limit of detection for moderate cases (mean $4.8 \pm 1.8 \mathrm{ng} / \mathrm{ml}$; range $0-40.0 \mathrm{ng} / \mathrm{ml}$ ). For follicles soaked in LPS in vitro, the concentrations of LPS in follicular fluid were higher than control follicular fluid for medium-sized follicles $(0.5 \pm 0.7 \mathrm{ng} / \mathrm{ml}$ versus $0 ; P<0.05)$ or large follicles $(74.2 \pm 31.1 \mathrm{ng} / \mathrm{ml}$ versus $0 ; P<0.01)$.

\section{LPS does not affect androstenedione production by theca cells}

Production of oestradiol by granulosa cells is dependent on the aromatisation of theca-derived androstenedione and the stage of follicle growth or development (Fortune 1994). Hence, cultured theca cells were challenged with LPS to determine whether $E$. coli affects androstenedione production. However, LPS treatment for $48 \mathrm{~h}$ did not affect the production of androstenedione, regardless of the follicle size from which the cells were isolated (Fig. 1A-C). In addition, there was no effect of LPS after $96 \mathrm{~h}$ treatment (data not shown) and the LPS challenge did not affect cell numbers ( $P>0.05$; Fig. 1D-F).

\section{Oestradiol production is directly inhibited following LPS treatment of granulosa cells}

Since peripheral plasma oestradiol concentrations are lower following uterine infection in vivo (Sheldon et al. 2002), and LPS does not modulate the production of androstenedione by theca cells in vitro, we investigated whether LPS had a direct effect on oestradiol production by granulosa cells. In the presence of optimum FSH and androstenedione concentrations as determined previously (Gutierrez et al. 1997), LPS inhibited oestradiol production by bovine granulosa cells, with the greatest impact on cells from dominant ( $>8 \mathrm{~mm}$ diameter) and recruited $(4-8 \mathrm{~mm})$ follicles (Fig. 2A-C). In addition, LPS also inhibited progesterone production by bovine granulosa cells from dominant and recruited follicles (Fig. 2D-F). The inhibition of oestradiol (Fig. 3A-C), but not progesterone (Fig. 3D-F), was still observed at $96 \mathrm{~h}$ after LPS treatment. However, LPS treatment was not associated with significant changes in cell numbers (Fig. 3G-I). To determine if granulosa cells were sensitive to lower concentrations of LPS associated 

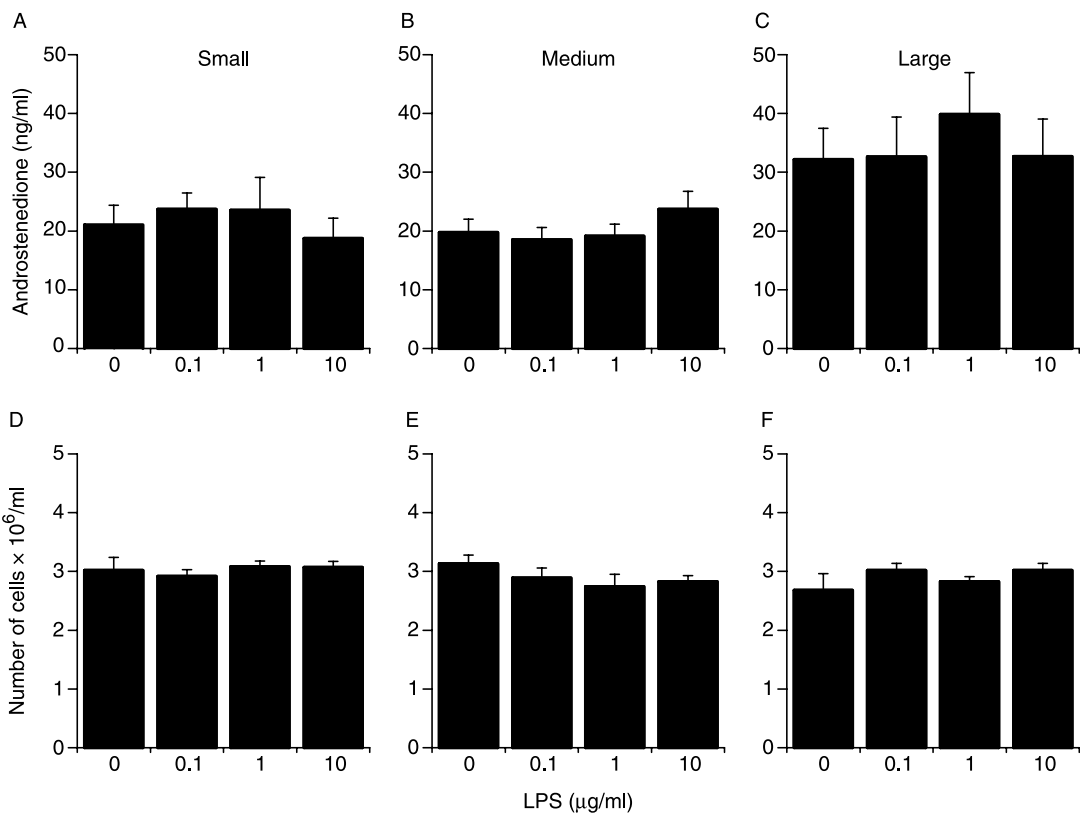

Figure 1 Androstenedione production of theca cells isolated from (A) small ( $<4 \mathrm{~mm}$ diameter), (B) medium (4-8 $\mathrm{mm}$ diameter) or (C) large ( $>8 \mathrm{~mm}$ diameter) bovine follicles. Theca cells were treated with LPS at the concentrations indicated. After $48 \mathrm{~h}$ treatment, supernatants were harvested and androstenedione production was measured by RIA. The number of theca cells $\left(\times 10^{6} / \mathrm{ml}\right)$ after $96 \mathrm{~h}$ culture are indicated $(\mathrm{D}$ to F). Numerical values are presented as the mean + S.E.M. of three experiments. with subclinical uterine disease, cells were treated with $0.1 \mathrm{ng} / \mathrm{ml}$ LPS, which reduced oestradiol production by granulosa cells from dominant follicles $(2.6 \pm 0.8$ vs $4.1 \pm 0.8 \mathrm{ng} / \mathrm{ml}, P<0.05)$ and tended to reduce oestradiol production by cells from recruited follicles $(1.9 \pm 0.5 \mathrm{vs}$ $3.4 \pm 0.8 \mathrm{ng} / \mathrm{ml}, P=0.09$ ) compared with control. Treatment of granulosa cells with $0.1,1$ and $10 \mu \mathrm{g} / \mathrm{ml}$ of a detoxified form of LPS had no effect on oestradiol secretion by cells from dominant follicles $(1.4 \pm 0.3$, $1.4 \pm 0.2$ and $1.5 \pm 0.2 \mathrm{ng} / \mathrm{ml}$ ) compared with control cells $(1.5 \pm 0.2 \mathrm{ng} / \mathrm{ml})$.

To determine whether the decrease in oestradiol production in granulosa cells from medium and large follicles was due to changes in responsiveness to $\mathrm{FSH}$ and/or the down-regulation of the enzyme required for oestradiol synthesis, expression of mRNA for the FSH receptor (FSHR) and aromatase were analysed. Following LPS challenge of granulosa cells isolated from dominant $(>8 \mathrm{~mm})$ follicles, only aromatase mRNA levels were down-regulated (Fig. 4A and C; FSHR, $P=0.11)$. Analysis of oestradiol receptor $\alpha(E R \alpha)$, $E R \beta$ and $\mathrm{LH}$ receptor (LHR) mRNA expression was determined to explore the effects of LPS on granulosa cell function. Granulosa cells isolated from recruited and dominant follicles expressed ER $\alpha$ mRNA, while only granulosa cells isolated from dominant follicles
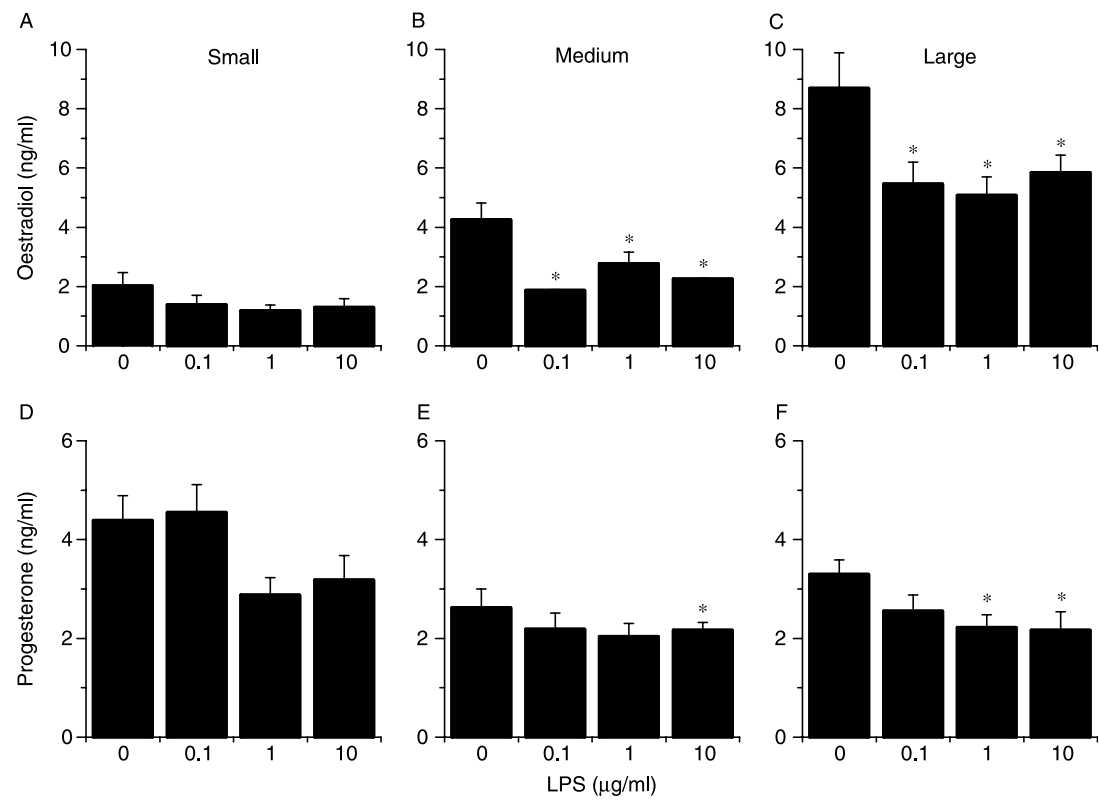

Figure 2 Oestradiol and progesterone production of granulosa cells isolated from (A and D) small $(<4 \mathrm{~mm}$ diameter), (B and $\mathrm{E})$ medium $(4-8 \mathrm{~mm}$ diameter) or ( $\mathrm{C}$ and $\mathrm{F}$ ) large ( $>8 \mathrm{~mm}$ diameter) bovine follicles. Granulosa cells were treated with LPS at the concentrations indicated. After $48 \mathrm{~h}$ treatment, supernatants were harvested and steroid production was measured by RIA. $* P<0.05$ compared with control, within follicle size. Numerical values are presented as the mean + S.E.M. of three experiments. 

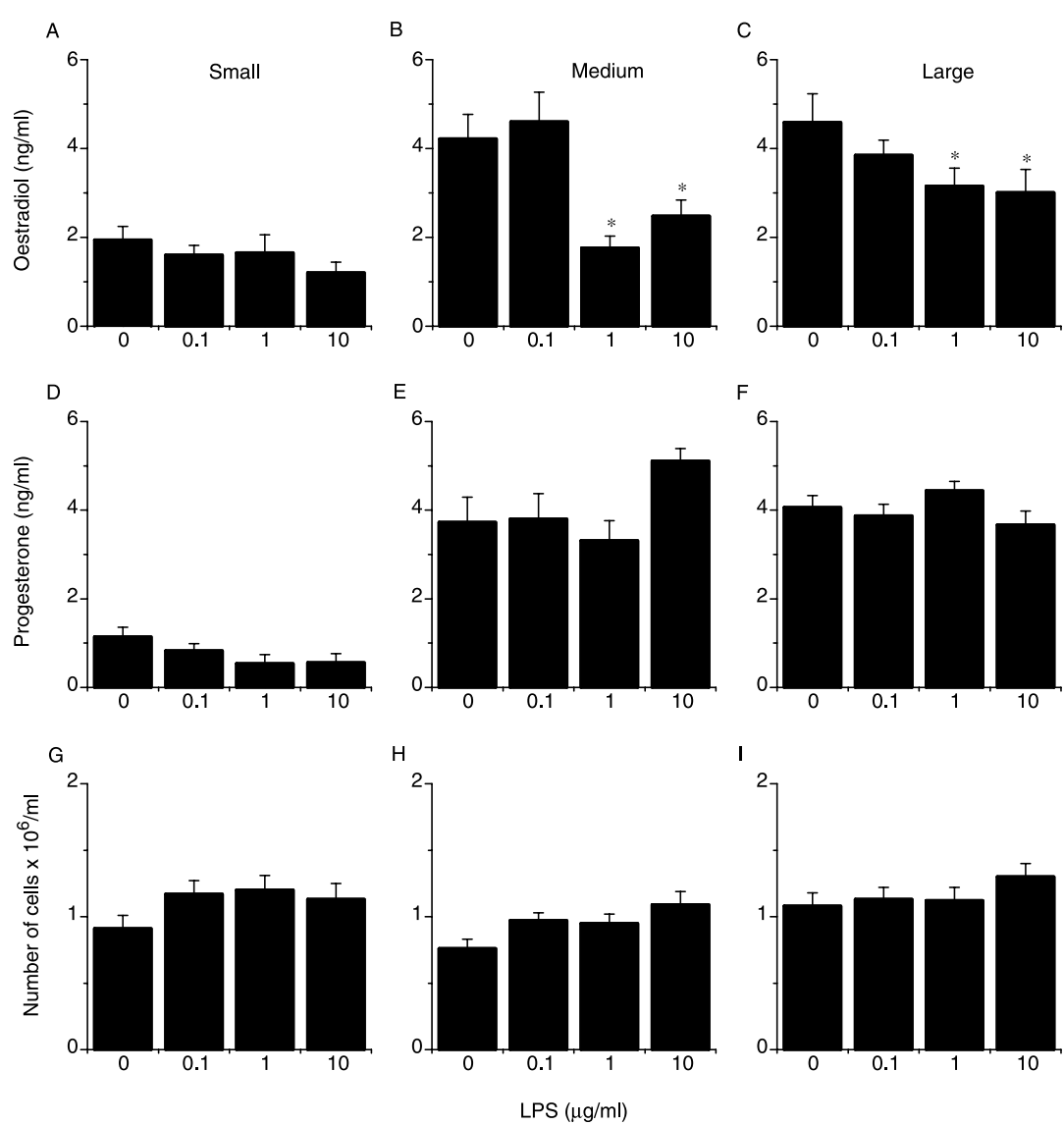

Figure 3 Oestradiol and progesterone production of granulosa cells isolated from (A and D) small ( $<4 \mathrm{~mm}$ diameter), ( $\mathrm{B}$ and $\mathrm{E})$ medium $(4-8 \mathrm{~mm}$ diameter) or ( $\mathrm{C}$ and $\mathrm{F}$ ) large ( $>8 \mathrm{~mm}$ diameter) bovine follicles. Granulosa cells were treated with LPS at the concentrations indicated. After $96 \mathrm{~h}$ treatment, supernatants were harvested and steroid production was measured by RIA. The number of granulosa cells $\left(\times 10^{6} / \mathrm{ml}\right)$ after $96 \mathrm{~h}$ culture are indicated (G to I). ${ }^{*} P<0.05$ compared with control, within follicle size. Numerical values are presented as the mean +S.E.M. of three experiments. expressed LHR mRNA and expression was not affected by LPS treatment (Fig. 4A). Transcripts for ER $\beta$ mRNA were not detectable in control or LPS-treated granulosa cells at $48 \mathrm{~h}$, but were expressed at $0 \mathrm{~h}$ by freshly isolated granulosa cells (data not shown).

\section{Granulosa cells express immune mediators}

Interleukin-1 (IL-1) plays an important role in immunity as well as in ovarian cell function (Spicer \& Alpizar 1994, Janeway et al. 2001, Gerard et al. 2004). Consequently, the expression of IL- $1 \alpha$ and IL- $1 \beta$ mRNA by granulosa cells was determined following LPS challenge. Granulosa cells isolated from medium and large follicles expressed transcripts for IL- $1 \alpha$ (Fig. 4B) but not IL-1 $\beta$ mRNA (data not shown). There was no significant difference in the IL- $1 \alpha$ mRNA expression following LPS treatment of cells isolated from the large follicle ( $P=0.12$, Fig. 4C).

In response to LPS treatment, immune cells produce TNF $\alpha$ and NO (Janeway et al. 2001, Akira \& Takeda 2004, Beutler 2004). Since granulosa cells responded to LPS, TNF $\alpha$ and NO were measured in the supernatants of cell cultures treated with LPS, but concentrations were below the limits of detection. Consequently, granulosa cells were analysed for the expression of TNF $\alpha$ and NO synthase (NOS2, formerly iNOS, inducible NOS) mRNA. Granulosa cells expressed TNF $\alpha$ but not NOS2 mRNA (Fig. 4B). As observed with IL-1 $\alpha$, TNF $\alpha$ mRNA was detected in granulosa cells isolated from medium and large follicles, but there was no significant regulation of TNF $\alpha$ mRNA following LPS treatment $(P=0.14$, Fig. 4C).

\section{Granulosa cells express TLR4, MD-2 and CD14 mRNA}

To ensure that the response to LPS was not mediated via contaminating immune cells, the expression of the panleukocyte marker, CD45, was determined by PCR. Granulosa cell cultures were free of contaminating immune cells (Fig. 5A). As granulosa cells responded to LPS challenge directly, we analysed the mRNA expression of the LPS receptor complex: TLR4, CD14 and MD-2. Granulosa cells isolated from medium and large follicles expressed TLR4, CD14 and MD-2 mRNA (Fig. 5B).

\section{Discussion}

Uterine infection with E. coli or infusion of LPS perturbs ovarian antral follicle growth and function (Xiao et al. 1998, Battaglia et al. 2000, Sheldon et al. 2002). In the 
A

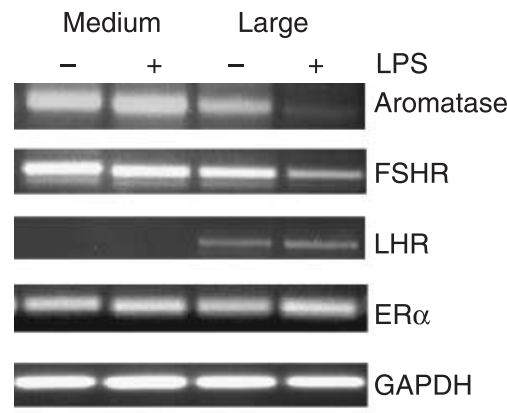

B

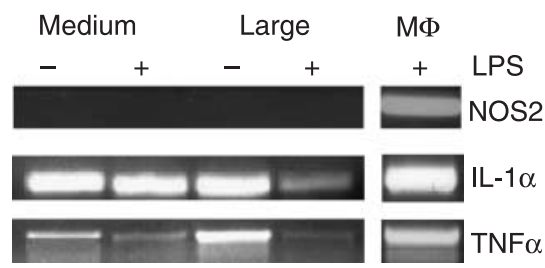

C

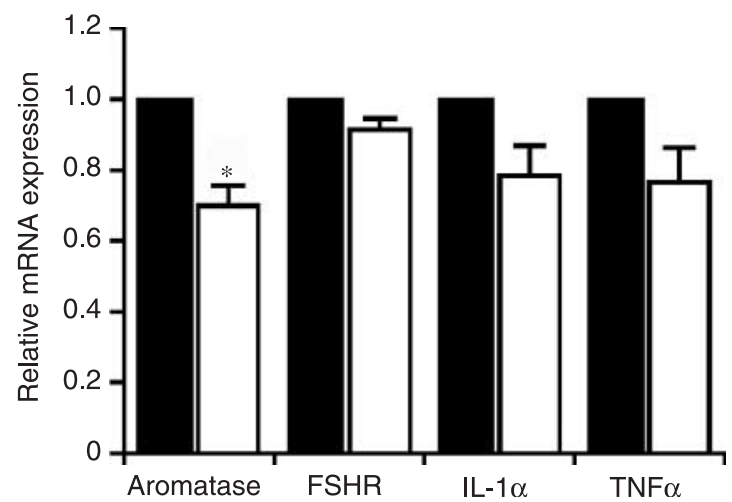

Figure 4 Analysis of gene expression by granulosa cells associated with reproductive function. Granulosa cells isolated from medium $(4-8 \mathrm{~mm}$ diameter) or large ( $>8 \mathrm{~mm}$ diameter) follicles were stimulated with $10 \mu \mathrm{g} / \mathrm{ml}$ LPS for $48 \mathrm{~h}$ and harvested, RNA was isolated and reverse transcribed as described in Materials and Methods. cDNA was analysed for the presence of (A) aromatase, FSHR, LHR, ER $\alpha$, and (B) NOS2, $\mathrm{IL}-1 \alpha$ and TNF $\alpha$ transcripts using the indicated primer pairs (Table 1). A representative result is shown $(n=3)$. (C) PCR bands were analysed and are represented as LPS treatment (open bar) relative to nil control (closed bar) for granulosa cells isolated from large ( $>8 \mathrm{~mm}$ diameter) follicles. Results are presented as the mean +S.E.M. of three experiments. ${ }^{*} P<0.05$ compared with control.

present study, we found LPS in follicular fluid from animals with uterine disease and treatment of granulosa cells with LPS in vitro suppressed oestradiol production in cells from recruited and dominant follicles. Furthermore, the pure populations of granulosa cells from the different stages of follicle growth expressed TLR4, CD14 and MD-2 mRNA transcripts, which constitute the specific receptor complex for LPS. The observations that theca cell androstenedione production was unaffected by LPS treatment but that granulosa cell aromatase transcripts were regulated provides an insight into a mechanism by which LPS may mediate its effect on follicle growth, development and function in the mammalian ovary.

In the whole animal, the effects of bacteria or LPS are most evident in large or pre-ovulatory antral follicles of several species (Xiao et al. 1998, Battaglia et al. 2000, Sheldon et al. 2002). In cattle with uterine infection, ovarian follicle growth is suppressed from $8 \mathrm{~mm}$ diameter, around the time of dominant follicle selection (Sheldon et al. 2002, Campbell et al. 2003). The lower peripheral plasma oestradiol concentrations are evident in the days before ovulation, but as oestradiol concentrations are in the $\mathrm{pg} / \mathrm{ml}$ range, it would be difficult to detect subtle differences in the whole animal before this (Sheldon et al. 2002). However, infusion of LPS suppresses plasma oestradiol concentrations within $24 \mathrm{~h}$, delaying the LH surge and ovulation (Suzuki et al. 2001).

To substantiate the concept that LPS is present in the follicular fluid of animals with uterine disease, ovarian follicular fluid was aspirated in vivo from animals in which the severity of uterine disease had been characterised (Moussavi et al. 2007). Animals with clinical disease had concentrations of LPS that ranged up to $0.8 \mu \mathrm{g} / \mathrm{ml}$ and normal animals did not have measurable concentrations of LPS in their ovarian follicular fluid, while animals with subclinical disease had intermediate concentrations. The high concentrations of LPS in ovarian follicular fluid in disease animals is lower than LPS concentrations reported in the uterus but higher than those reported in peripheral plasma (Dohmen et al. 2000, Mateus et al. 2003, Williams et al. 2007). This suggests that there may be some localised transfer of LPS by the intimate vasculature that links the uterus and ovary, as is the case for prostaglandin $F_{2 \alpha}$ (Ginther 1974, Ford et al. 1979). To support further the concept that LPS can cross the basement membrane of the ovarian follicle, dissected follicles were maintained in culture media containing $10 \mu \mathrm{g} / \mathrm{ml}$ LPS for $18 \mathrm{~h}$ in vitro. Despite the lack of active vasculature, LPS was found in the follicular fluid of medium and particularly large follicles, probably reflecting the surface area available for diffusion of LPS. Taken together these data support the in vivo observations that LPS has a localised effect in the ovarian follicle of cattle and sheep (Battaglia et al. 2000, Sheldon et al. 2002).

Oestradiol is produced by granulosa cell aromatisation of theca-derived androgens under the stimulation of gonadotrophins (Fortune 1994). In the present study, treatment of theca cells with LPS did not affect androstenedione production or cell survival, whereas oestradiol secretion was suppressed by LPS treatment of granulosa cells, and the effect was most marked in cells from medium and large follicles, concurring with the whole animal observations. Androstenedione and oestradiol secretion from the theca and granulosa cells respectively were maintained for $96 \mathrm{~h}$ under serum-free 

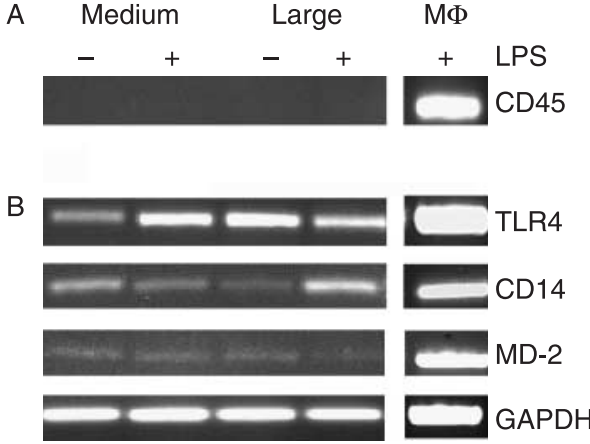

Figure 5 Analysis of LPS receptor complex and immune mediator gene expression by granulosa cells. Granulosa cells isolated from medium (4-8 $\mathrm{mm}$ diameter) or large ( $>8 \mathrm{~mm}$ diameter) follicles were stimulated with $10 \mu \mathrm{g} / \mathrm{ml}$ LPS for $48 \mathrm{~h}$ and harvested, RNA was isolated and reverse transcribed as described in Materials and Methods. CDNA was analysed for the presence of (A) CD45, (B) TLR4, CD14, MD-2, $\mathrm{GAPDH}$, using the indicated primer pairs (Table 1). A representative result is shown $(n=3)$.

culture conditions, as previously described (Gutierrez et al. 1997, Glister et al. 2005); and the LPS suppression of granulosa cell oestradiol secretion was also maintained in the present study. This would appear to be a direct effect of LPS on granulosa cells as they were cultured in the presence of previously determined optimal concentrations of androstenedione and $\mathrm{FSH}$ and no further addition of androstenedione or FSH was made to the treatment cultures (Gutierrez et al. 1997); furthermore, cell survival was unaffected even after $96 \mathrm{~h}$ LPS treatment. The sensitivity of granulosa cells was confirmed further by the reduced oestradiol secretion when cells were treated with $0.1 \mathrm{ng} / \mathrm{ml}$ LPS and the specificity of the LPS response confirmed by treatment with detoxified LPS, which did not affect oestradiol secretion. The present bovine data contrast somewhat with the rat where LPS suppressed theca cell androstenedione production, although LPS also perturbed LH-stimulated oestradiol production from rat granulosa cells without affecting cell viability, similar to the present study (Taylor \& Terranova 1995, 1996). However, there are likely to be differences between species and different stages of follicular development. The strength of the present study is that granulosa cells were derived from follicles reflecting the physiological stages of development in a biologically relevant species where disease causes infertility.

Oestradiol secretion by granulosa cells is dependent on gonadotrophins binding to G-protein-coupled receptors driving aromatisation of androstenedione (Dierich et al. 1998, Ma et al. 2004). In the whole animal, LPS can perturb ovarian follicle function by disruption of pituitary LH secretion directly or by suppressing peripheral plasma oestradiol concentrations (Battaglia et al. 2000, Suzuki et al. 2001, Karsch et al. 2002). However, effects on the pituitary are only part of the explanation as peripheral plasma oestradiol concentrations are lower in the face of normal $\mathrm{LH}$ concentrations (Battaglia et al. 2000); and plasma FSH concentrations are unaffected by uterine infection (Sheldon et al. 2002). In the present study, FSHR mRNA was expressed in granulosa cells from medium and large follicles but LHR was only present in cells from large follicles, in agreement with previous observations (Bao et al. 1997). However, the expression of FSHR and LHR was unaffected by LPS in granulosa cells. On the other hand, aromatase transcript expression in granulosa cells was down-regulated in the cells from the dominant follicles following incubation with LPS, which may affect steroidogenesis (Fortune 1994, Richards 1994). In the rat, LPS similarly inhibits gonadotrophin-induced aromatisation of androgens (Taylor \& Terranova 1996). However, it is not clear why the expression of aromatase was not affected in cells from the recruited follicles. Freshly isolated granulosa cells expressed $E R \alpha$ and $E R \beta$, in agreement with previous observations (Berisha et al. 2002). Transcripts for ER $\alpha$ were unchanged by LPS treatment and ER $\beta$ was not detected in control or treated granulosa cells, appearing to be down-regulated by culture. Thus, the effect of LPS on oestradiol biosynthesis was not due to the inability of the cells to respond to oestradiol.

The present study used CD45 expression to demonstrate the absence of contaminating leukocytes in the granulosa cell cultures, suggesting a direct response of granulosa cells to LPS. This is important because the granulosa cell compartment within the basement membrane of the ovarian follicle is devoid of immune cells in vivo (Petrovska et al. 1996). The TLR4, CD14 and MD-2 complex is required for binding LPS to leukocytes, leading to signal transduction and activation of the innate immune response (Akira \& Takeda 2004, Beutler 2004, Akira et al. 2006). However, TLR4 has been identified on cells other than leukocytes, including uterine epithelial and stromal cells (Hirata et al. 2005, Herath et al. 2006b). Indeed, analysis of mRNA transcripts in the present study indicated that granulosa cells from medium and large ovarian follicles expressed mRNA for TLR4 and the accessory molecules, CD14 and MD-2. Regulation of these genes in granulosa cells following LPS stimulation requires further validation and was beyond the scope of the present study. Interestingly, a recent study showed that murine granulosa cells around the time of ovulation increased the expression of TLR4 transcripts in response to LPS challenge (Shimada et al. 2006). Thus, it appears that granulosa cells have immune capabilities.

Recognition of LPS by immune cells results in the production of pro-inflammatory molecules such as IL-1 $\beta$, TNF $\alpha$ and NO (Janeway et al. 2001, Akira \& Takeda 2004, Beutler 2004). Although these proinflammatory molecules play an important role in ovulation in many species (Machelon \& Emilie 1997, Bornstein et al. 2004, Gerard et al. 2004), they also 
suppress granulosa cell aromatase expression and oestrogen biosynthesis (Adashi et al. 1989, Spicer \& Alpizar 1994, Ghersevich et al. 2001). Since granulosa cell oestradiol production was impaired following LPS challenge in the present study, we investigated whether LPS enhanced the production of inflammatory mediators that could compromise steroidogenesis. However, LPS did not increase IL-1 $\alpha$ or TNF transcripts in granulosa cells isolated from dominant follicles. Thus, the perturbation of granulosa cell steroidogenesis appears to be a direct effect of LPS.

In conclusion, bovine granulosa cells express the LPS innate immune receptor gene complex, comprising TLR4, MD-2 and CD14, throughout follicle recruitment and dominance. The treatment of granulosa cells with LPS in vitro suppressed the secretion of oestradiol but did not affect the secretion of androstenedione from theca cells or the survival of either granulosa or theca cells. This impairment of granulosa cell function may in part be mediated via the down-regulation of aromatase gene expression. As granulosa cell oestradiol production is pivotal during follicle development and these cells nurture the oocyte until ovulation, the immune capability of these granulosa cells and their response to patho-physiological concentrations of LPS in vivo is likely to be an important mechanism underlying the infertility associated with bacterial infection.

\section{Materials and Methods}

\section{LPS measurement in follicular fluid}

Follicular fluid was aspirated using a sterile needle guided by transrectal ultrasonography, from postpartum (40-60 days) dairy cows $(n=58)$ in which the uterine disease had been evaluated as part of an independent study (Moussavi et al. 2007). Briefly, the uterine disease cytology evaluates the level of inflammation from 0 (normal; no inflammation), 1 (subclinical; mild inflammation), 2 (subclinical; moderate inflammation) to 3 (clinical endometritis). Samples were stored in endotoxin-free glass or polystyrene tubes (Lonza, Basel, Switzerland) at $-20^{\circ} \mathrm{C}$ until analysed. Concentrations of bacterial LPS were measured in samples using the QCL1000 Chromogenic Limulus Amebocyte Lysate (LAL) Endpoint Assay Kit (Lonza) following the manufacturer's guidelines. Samples were thawed, diluted in endotoxin-free $0.05 \mathrm{M}$ Tris and tested for non-specific LAL inhibition by comparing samples spiked with a known concentration of LPS with unspiked samples. Samples with evidence of LAL inhibition were heated in a water bath at $75^{\circ} \mathrm{C}$ for 30 min using temperatures and times validated in our laboratory to remove non-specific inhibitors of the LAL reaction (Williams et al. 2007). Samples were then mixed with the LAL substrate reagent and assayed in duplicate in 96-well endotoxin-free microplates (Corning, Lowell, MA, USA) alongside standard curve LPS concentrations of $0.01,0.25,0.5,1.0$ and 5 endotoxin units $/ \mathrm{ml}(10 \mathrm{eu}=1 \mathrm{ng}$ LPS) in serum. Serial dilutions were made in $50 \mathrm{mM}$ Tris until concentrations were measurable in the linear part of the standard curve. Internal recovery as determined using positively spiked serum samples was $>80 \%$ and the intra- and inter-assay coefficients of variation were 4.0 and $7.2 \%$ respectively and the limit of detection was $0.01 \mathrm{ng} / \mathrm{ml}$. To establish further that LPS crosses the ovarian follicle basement membrane, bovine ovaries were obtained from a slaughterhouse and eight medium $(4-8 \mathrm{~mm}$ diameter) and large follicles ( $>8 \mathrm{~mm}$ diameter) dissected and maintained in $6 \mathrm{ml}$ Dulbecco's modified Eagle's medium (DMEM)/F12 (Sigma) containing $10 \mu \mathrm{g} / \mathrm{ml}$ LPS (Sigma: E. coli serotype 055:B5) for $18 \mathrm{~h}$ at $37^{\circ} \mathrm{C}$. Ovaries were washed six times in water and endotoxin-free Tris, and follicular fluid aspirated using a sterile needle (25 G) and syringe. Concentrations of LPS were measured as previously described.

\section{Cell cultures}

Granulosa and theca cells were obtained and cultured separately in serum-free media as previously described (Gutierrez et al. 1997, Glister et al. 2005). Briefly, bovine ovaries were collected at a local abattoir immediately after slaughter and returned to the laboratory within $1 \mathrm{~h}$. Follicles were isolated manually by dissection and selected for isolation of cells if they had a translucent appearance, a wellvascularised theca and clear follicular fluid with no visible debris or blood. Follicles were measured using a grid or callipers and classed by external diameter as small $(<4 \mathrm{~mm}$ diameter), medium (4-8 $\mathrm{mm}$ diameter) or large $(>8 \mathrm{~mm}$ diameter), reflecting their gonadotrophin dependence and changes in the expression of steroidogenic enzymes and LH receptors (Fortune 1994, Campbell et al. 2003). At $4 \mathrm{~mm}$ diameter, follicles are recruited into follicle waves in cattle and become responsive to $\mathrm{FSH}$, with increased expression of aromatase (Xu et al. 1995). From $8 \mathrm{~mm}$ diameter, granulosa cells express $\mathrm{LH}$ receptors and these selected dominant follicles require pulsatile $\mathrm{LH}$ stimulation to continue growing (Xu et al. 1995). Follicles were hemisected and granulosa cells obtained by flushing the hemisected shells and collecting the cell-rich supernatant (Gutierrez et al. 1997). Theca cells were then obtained by manually peeling the basal lamina from the hemisected follicular shells and digesting for $45 \mathrm{~min}$ at $37^{\circ} \mathrm{C}$ in digestion medium containing $1 \mathrm{mg} / \mathrm{ml}$ collagenase (Sigma) and $3 \mathrm{mg} / \mathrm{ml}$ trypsin inhibitor (Sigma) in a moving water bath, and then collecting the cell-rich supernatant as previously described (Glister et al. 2005). Cells were $>80 \%$ viable as determined by Trypan blue exclusion. Both granulosa and theca cells were plated at a density of $1.5 \times 10^{6}$ cell $\mathrm{s} / \mathrm{ml}$ in 96 -well plates (Nunc, Lutterworth, UK) using serum-free media, with $10^{-7} \mathrm{M}$ androstenedione for granulosa cells, and maintained at $37^{\circ} \mathrm{C}, 5 \% \mathrm{CO}_{2}$ in air, in a humidified incubator (Gutierrez et al. 1997, Glister et al. 2005). Oestradiol and androstenedione production by granulosa and theca cells respectively were induced and maintained in response to physiological concentrations of $\mathrm{FSH}(1 \mathrm{ng} / \mathrm{ml})$ or $\mathrm{LH}(160 \mathrm{pg} / \mathrm{ml})$ respectively as previously described (Gutierrez et al. 1997, Glister et al. 2005).

Macrophages were isolated from peripheral blood mononuclear cells (PBMC) using blood collected from the local abattoir. PBMCs were separated by density gradient centrifugation on $1.083 \mathrm{~g} / \mathrm{ml}$ Histopaque (Sigma) and cell viability 
was $>95 \%$, as determined by Trypan blue exclusion. Cells were plated in six-well plates at a density of $5 \times 10^{6}$ cells $/ \mathrm{ml}$ in DMEM (low glucose; Sigma) supplemented with 10\% FBS (PAA Laboratories $\mathrm{GmbH}$, Pasching, Austria), $50 \mathrm{IU} / \mathrm{ml}$ penicillin, $50 \mu \mathrm{g} / \mathrm{ml}$ streptomycin, $2.5 \mu \mathrm{g} / \mathrm{ml}$ amphotericin B and $240 \mathrm{U} / \mathrm{ml}$ Nystatin (Sigma). After 2 h, non-adherent cells were removed and adherent cells (monocytes) were differentiated in culture for a further 3 days to yield macrophages. Macrophages, which were used as positive controls for PCR, were cultured in the presence or absence of $1 \mu \mathrm{g} / \mathrm{ml}$ LPS (Sigma: E. coli serotype 055:B5) for $24 \mathrm{~h}$, at which time cells were collected for RNA extraction.

\section{Cell culture challenge}

After an initial 48-h establishment period, the ovarian cell culture media were removed and replaced with fresh media containing 0, 0.1, 1 or $10 \mu \mathrm{g} / \mathrm{ml}$ LPS (Sigma: E. coli serotype 055:B5). These concentrations are similar to those in follicular fluid of animals with clinical disease and LPS concentrations used for immune cell work (Poltorak et al. 1998, Shell et al. 2005, Tsatsanis et al. 2006), and preliminary studies with bovine cells covering the range from $1 \mathrm{ng} / \mathrm{ml}$ to $10 \mu \mathrm{g} / \mathrm{ml}$ where clear effects were seen with concentrations $>0.1 \mu \mathrm{g} / \mathrm{ml}$. Indeed, in the original descriptions of the role of TLR4, maximal responses were obtained at $10 \mu \mathrm{g} / \mathrm{ml}$ E. coli O55:B5 LPS (Hoshino et al. 1999). After $48 \mathrm{~h}$ treatment, media were carefully removed and stored at $-20{ }^{\circ} \mathrm{C}$ until assayed and fresh media containing $0,0.1,1$ or $10 \mu \mathrm{g} / \mathrm{ml}$ LPS (Sigma: E. coli serotype 055:B5) were added for a further 48-h treatment period (termed $96 \mathrm{~h}$ ) to confirm that the granulosa cells maintained physiological function under serum-free conditions and determine if any effects of LPS on granulosa cells also persisted. At $96 \mathrm{~h}$, media were removed and stored at $-20^{\circ} \mathrm{C}$ until assayed, the number of viable cells determined by neutral red dye uptake as previously described (Campbell et al. 1996), and where the maximum responses were observed $(10 \mu \mathrm{g} / \mathrm{ml}$ LPS), cells were collected for RNA isolation. To explore if granulosa cells responded to concentrations of LPS in follicular fluid of animals with subclinical uterine disease in vivo, the experiments were repeated using $0.1 \mathrm{ng} / \mathrm{ml}$ LPS (Sigma: E. coli serotype 055:B5) for a 48-h treatment period. To confirm further that the effects of treatments were associated with LPS, granulosa cells from dominant follicles were treated with $0.1,1$ and $10 \mu \mathrm{g} / \mathrm{ml}$ of a detoxified form of LPS (Sigma: detoxified from $E$. coli serotype 055:B5), media alone as a negative control, and $0.1 \mu \mathrm{g} / \mathrm{ml}$ LPS (Sigma: E. coli serotype 055.B5) as a positive control.

\section{Hormone assays}

Culture supernatants were analysed by RIA as previously described (Abayasekara et al. 1993), adapted for androstenedione, oestradiol or progesterone. Samples were diluted in $0.05 \mathrm{M}$ Tris buffer containing $0.1 \%$ gelatin and $0.01 \%$ sodium azide. Standards, antiserum and tritiated tracer were purchased from Sigma, Biogenesis (Biogenesis, Kidlington, UK) and Amersham International PLC (Amersham) respectively. The limit of detection for oestradiol, progesterone and

Table 1 Primer sequences for Toll-like receptor-4 (TLR4), CD14, MD-2, CD45, oestradiol receptor $\alpha$ (ER $\alpha$ ), ER $\beta$, aromatase, follicle-stimulating hormone receptor (FSHR), luteinising hormone receptor (LHR), interleukin-1 $\alpha$ (IL-1 $\alpha$ ), IL-1 $\beta$, nitric oxide synthase (NOS2, formerly inducible NOS), tumour necrosis factor $\alpha(\mathrm{TNF} \alpha)$ and GAPDH.

\begin{tabular}{|c|c|c|c|c|c|}
\hline Gene & Primer & Sequence $\left(5^{\prime}-3^{\prime}\right)$ & Size & $\boldsymbol{T}_{\mathbf{m}}\left({ }^{\circ} \mathrm{C}\right)$ & Accession no. \\
\hline \multirow[t]{2}{*}{ TLR4 } & Sense & CTT GCG TAC AGG TTG TTC CTA A & 153 & 56 & NM174198 \\
\hline & Antisense & CTG GGA AGC TGG AGA AGT TAT G & & & \\
\hline \multirow[t]{2}{*}{ CD14 } & Sense & GGG TAC TCT СТG CTC AAG GAA C & 199 & 56 & NM174008 \\
\hline & Antisense & CTT GGG CAA TGT TCA GCA C & & & \\
\hline \multirow[t]{2}{*}{ MD-2 } & Sense & GGG AAG CCG TGG AAT ACT CTA T & 204 & 54 & DQ319076 \\
\hline & Antisense & CCC CTG AAG GAG AAT TGT ATT G & & & \\
\hline \multirow[t]{2}{*}{ CD45 } & Sense & CTC GAT GTT AAG CGA GAG GAA T & 185 & 56 & AJ400864 \\
\hline & Antisense & ТCT TCA TCT ТCС ACG CAG TCT A & & & \\
\hline \multirow[t]{2}{*}{$\mathrm{ER} \alpha$} & Sense & TCA GGC TAC CAT TAC GGA GTT T & 169 & 60 & AY538775 \\
\hline & Antisense & CCA CTT CAT AGC ACT TGC GTA G & & & \\
\hline \multirow[t]{2}{*}{ ER $\beta$} & Sense & CTT CGT GGA GCT CAG CCT GT & 262 & 60 & NM174051 \\
\hline & Antisense & GAG ATA TTC TTT GTG TTG GAG TTT & & & \\
\hline \multirow{2}{*}{ Aromatase } & Sense & CGC AAA GCC TTA GAG GAT GA & 211 & 53 & U18447 \\
\hline & Antisense & ACC ATG GCG ATG TAC TTT CC & & & \\
\hline \multirow[t]{2}{*}{ FSHR } & Sense & GCC AAG TCA ACT TAC CGC TT & 193 & 56 & NM174061 \\
\hline & Antisense & TGA CCC CTA GCC TGA GTC AT & & & \\
\hline \multirow[t]{2}{*}{ LHR } & Sense & TGT TCT CCT GAC CAG TCG TTA CAA & 743 & 56 & BTU20504 \\
\hline & Antisense & AAT GCC TTT GTG AAA ATT GCG TAC & & & \\
\hline \multirow[t]{2}{*}{ IL-1 $\alpha$} & Sense & AGA GGA TTC TCA GCT TCC TGT G & 224 & 54 & NM174092 \\
\hline & Antisense & ATT TTT CTT GCT TTG TGG CAA T & & & \\
\hline \multirow[t]{2}{*}{ IL-1 $\beta$} & Sense & GAG GAG CAT CCT TTC ATT CAT C & 229 & 56 & X54796 \\
\hline & Antisense & TTC CTC TCC TTG TAC GAA GCT C & & & \\
\hline \multirow[t]{2}{*}{ NOS2 } & Sense & GGA CAG TAA AGA CGT CTC CAG AA & 197 & 54 & AF340236 \\
\hline & Antisense & TAT GGT CAA ACT TTT GGG GTT C & & & \\
\hline \multirow[t]{2}{*}{ TNF $\alpha$} & Sense & ACT CAG GTC CTC TTC TCA AGC C & 774 & 56 & BTTNFG \\
\hline & Antisense & ATG ATC CCA AAG TAG ACC TGC C & & & \\
\hline \multirow[t]{2}{*}{ GAPDH } & Sense & GGG GTG AAC CAC GAG AAG TAT AA & 120 & 56 & BC102589 \\
\hline & Antisense & CСС TCC ACG ATG CCA AAG T & & & \\
\hline
\end{tabular}


androstenedione was $80 \mathrm{pg} / \mathrm{ml}$. The respective intra- and interassay coefficients of variation were 8.8 and $9.9 \%$ for oestradiol, 3.1 and $12.6 \%$ for progesterone, and 3.6 and $16.5 \%$ for androstenedione.

\section{Determination of immune mediators}

Concentrations of bioactive tumour necrosis factor $\alpha$ (TNF $\alpha$ ) were measured as previously described (Herath et al. 2006b). Briefly, rat fibroblast L929 cells were cultured in DMEM supplemented with $12.5 \%$ FBS, $50 \mathrm{IU} / \mathrm{ml}$ penicillin and $50 \mu \mathrm{g} / \mathrm{ml}$ streptomycin. Cells were plated at a density of $2.5 \times 10^{4}$ cells per $100 \mu \mathrm{l}$ medium in 96-well plates (Nunc). Cytotoxicity was determined by the colorimetric MTT assay involving the addition of $0.1 \mu \mathrm{g} / \mathrm{ml}$ MTT dye (Sigma-Aldrich) to each well and incubating for $2-4 \mathrm{~h}$ at $37^{\circ} \mathrm{C}$ in a $5 \% \mathrm{CO}_{2}$ atmosphere. The cells were lysed using $100 \mu \mathrm{l}$ DMSO (Sigma-Aldrich) per well and colour development read at $560 \mathrm{~nm}$ on a Spectra Max 250 (Molecular Devices, Wokingham, UK). The limit of detection was $10 \mathrm{pg} / \mathrm{ml}$; standards were made using recombinant human TNF $\alpha$ (Sigma) and cross-reactivity was confirmed using recombinant bovine TNF $\alpha$ (kindly provided by Prof. C Howard, Institute for Animal Health, Compton, UK).

Concentrations of nitric oxide (NO) were measured using the Greiss Reagent System (Promega) according to the manufacturer's instructions. The limit of detection was $2.5 \mu \mathrm{M}$.

\section{PCR}

Total RNA was isolated from cell cultures using the RNeasy Mini Kit (Qiagen) and quantitated using a NanoDrop spectrophotometer (ND-1000 Spectrophotometer, NanoDrop Technologies Inc., Wilmington, DE, USA). Following DNase treatment (Promega), RNA was reverse transcribed into firststrand cDNA using SuperScript II RNase $\mathrm{H}^{-}$Reverse Transcriptase (Invitrogen, Life Technologies) according to the manufacturer's protocols. Amplification of $50 \mathrm{ng}$ cDNA used the following conditions, denaturation for $5 \mathrm{~min}$ at $94{ }^{\circ} \mathrm{C}$, followed by $94{ }^{\circ} \mathrm{C}$ for $30 \mathrm{~s}, 54-56{ }^{\circ} \mathrm{C}$ (Table 1) for $30 \mathrm{~s}$ and $72{ }^{\circ} \mathrm{C}$ for $30 \mathrm{~s}$, followed by a final extension of $5 \mathrm{~min}$ at $72{ }^{\circ} \mathrm{C}$. Each primer was optimised for $T_{\mathrm{m}}$ and cycle number to ensure that semi-quantitative differences in expression could be detected. A control reaction, omitting cDNA template, was performed to confirm the absence of contamination and macrophage cDNA was used as an external control to ensure optimal PCR conditions. Primer combinations were designed using the Primer 3 software package (http://frodo.wi.mit.edu/), and were chosen on the criteria that the amplified product would traverse an exon/intron boundary and that the product was short enough to ensure optimum amplification. Primers were purchased from MWG (https://ecom.mwgdna.com) and were analysed for primer set-specific gene amplification using the nucleotide BLAST database (http://www.ncbi.nlm.nih.gov/ blast). Primer sequences are presented in Table 1 and housekeeping gene primer conditions were optimised as previously described (Fenwick et al. 2006). PCR bands were analysed by densitometry using Quantity One 1-D Analysis Software version 4.6.2 (Bio-Rad). Products were sequenced using an $\mathrm{ABI} 3100$ genetic analyzer and Bigdye Terminator 3.1 from $\mathrm{ABI}$ (Foster City, CA, USA) and were verified using the BLAST database.

\section{Statistical analysis}

Results are reported as the arithmetic mean \pm s.E.M., and significance ascribed when $P<0.05$. Hormone data were log transformed to yield variance homogeneity and the effects of treatments were explored using General Linear Model Univariate analysis in SPSS version 14.0 (SPSS Inc., Chicago, IL, USA), where treatment was the fixed variable and animal was fitted as a random variable. Post hoc comparisons between treatment and control were made using the Dunnett's $t$-test. Densitometry and LPS values were compared using independent $t$-test.

\section{Acknowledgements}

We thank A Miller, K Sibley, N Santos and R Hammond for technical assistance and W R Butler for access to follicular fluid samples. This work was supported by grants from the Biotechnology and Biological Sciences Research Council (Grant No. S19795) and the Wellcome Trust (Grant No. 064155). MS is a BBSRC Research Development Fellow (Grant No. BB/D02028X/1). The authors declare that there is no conflict of interest that would prejudice the impartiality of this scientific work.

\section{References}

Abayasekara DR, Michael AE, Webley GE \& Flint AP 1993 Mode of action of prostaglandin F2 alpha in human luteinized granulosa cells: role of protein kinase C. Molecular and Cellular Endocrinology 97 81-91.

Adashi EY, Resnick CE, Croft CS \& Payne DW 1989 Tumor necrosis factor alpha inhibits gonadotropin hormonal action in nontransformed ovarian granulosa cells. A modulatory noncytotoxic property. Journal of Biological Chemistry 264 11591-11597.

Akira S \& Takeda K 2004 Toll-like receptor signalling. Nature Reviews. Immunology 4 499-511.

Akira S, Uematsu S \& Takeuchi O 2006 Pathogen recognition and innate immunity. Cell 124 783-801.

Bao B, Garverick HA, Smith GW, Smith MF, Salfen BE \& Youngquist RS 1997 Changes in messenger ribonucleic acid encoding luteinizing hormone receptor, cytochrome $\mathrm{P} 450$-side chain cleavage, and aromatase are associated with recruitment and selection of bovine ovarian follicles. Biology of Reproduction 56 1158-1168.

Battaglia DF, Krasa HB, Padmanabhan V, Viguie C \& Karsch FJ 2000 Endocrine alterations that underlie endotoxin-induced disruption of the follicular phase in ewes. Biology of Reproduction 62 45-53.

Berisha B, Pfaffl MW \& Schams D 2002 Expression of estrogen and progesterone receptors in the bovine ovary during estrous cycle and pregnancy. Endocrine 17 207-214.

Beutler B 2004 Inferences, questions and possibilities in Toll-like receptor signalling. Nature 430 257-263.

Bornstein SR, Rutkowski H \& Vrezas I 2004 Cytokines and steroidogenesis. Molecular and Cellular Endocrinology 215 135-141.

Butler D 2004 The fertility riddle. Nature 432 38-39.

Campbell BK, Scaramuzzi RJ \& Webb R 1996 Induction and maintenance of oestradiol and immunoreactive inhibin production with FSH by ovine granulosa cells cultured in serum-free media. Journal of Reproduction and Fertility 106 7-16.

Campbell BK, Souza C, Gong J, Webb R, Kendall N, Marsters P, Robinson G, Mitchell A, Telfer EE \& Baird DT 2003 Domestic ruminants 
as models for the elucidation of the mechanisms controlling ovarian follicle development in humans. Reproduction. Supplement $\mathbf{6 1}$ 429-443.

Dierich A, Sairam MR, Monaco L, Fimia GM, Gansmuller A, LeMeur M \& Sassone-Corsi P 1998 Impairing follicle-stimulating hormone (FSH) signaling in vivo: targeted disruption of the $\mathrm{FSH}$ receptor leads to aberrant gametogenesis and hormonal imbalance. PNAS 95 13612-13617.

Dohmen MJ, Joop K, Sturk A, Bols PE \& Lohuis JA 2000 Relationship between intra-uterine bacterial contamination, endotoxin levels and the development of endometritis in postpartum cows with dystocia or retained placenta. Theriogenology 54 1019-1032.

Fenwick MA, Fitzpatrick R, Kenny DA, Diskin MG, Patton J, Murphy JJ \& Wathes DC 2006 Interrelationships between negative energy balance (NEB) and IGF regulation in liver of lactating dairy cows. Domestic Animal Endocrinology doi:10.1016/j.domaniend.2006.10.002.

Ford SP, Chenault JR \& Echternkamp SE 1979 Uterine blood flow of cows during the oestrous cycle and early pregnancy: effect of the conceptus on the uterine blood supply. Journal of Reproduction and Fertility 56 53-62.

Fortune JE 1994 Ovarian follicular growth and development in mammals. Biology of Reproduction 50 225-232.

Gerard N, Caillaud M, Martoriati A, Goudet G \& Lalmanach AC 2004 The interleukin-1 system and female reproduction. Journal of Endocrinology 180 203-212.

Ghersevich S, Isomaa V \& Vihko P 2001 Cytokine regulation of the expression of estrogenic biosynthetic enzymes in cultured rat granulosa cells. Molecular and Cellular Endocrinology 172 21-30.

Ginther OJ 1974 Internal regulation of physiological processes through local venoarterial pathways: a review. Journal of Animal Science 39 550-564.

Glister C, Richards SL \& Knight PG 2005 Bone morphogenetic proteins (BMP) -4, -6, and -7 potently suppress basal and luteinizing hormoneinduced androgen production by bovine theca interna cells in primary culture: could ovarian hyperandrogenic dysfunction be caused by a defect in thecal BMP signaling? Endocrinology 146 1883-1892.

Gutierrez CG, Campbell BK \& Webb R 1997 Development of a long-term bovine granulosa cell culture system: induction and maintenance of estradiol production, response to follicle-stimulating hormone, and morphological characteristics. Biology of Reproduction 56 608-616.

Herath S, Dobson H, Bryant CE \& Sheldon IM 2006a Use of the cow as a large animal model of uterine infection and immunity. Journal of Reproductive Immunology 69 13-22.

Herath S, Fischer DP, Werling D, Williams EJ, Lilly ST, Dobson H, Bryant CE \& Sheldon IM $2006 b$ Expression and function of Toll-like receptor 4 in the endometrial cells of the uterus. Endocrinology 147 562-570.

Hirata T, Osuga Y, Hirota Y, Koga K, Yoshino O, Harada M, Morimoto C, Yano T, Nishii O, Tsutsumi $\mathbf{O}$ et al. 2005 Evidence for the presence of Toll-like receptor 4 system in the human endometrium. Journal of Clinical Endocrinology and Metabolism 90 548-556.

Hoshino K, Takeuchi O, Kawai T, Sanjo H, Ogawa T, Takeda Y, Takeda K \& Akira S 1999 Cutting edge: Toll-like receptor 4 (TLR4)-deficient mice are hyporesponsive to lipopolysaccharide: evidence for TLR4 as the Lps gene product. Journal of Immunology 162 3749-3752.

Janeway CA Jr, Travers P, Walport M \& Shlomchik MJ 2001 Infectious agents and how they cause disease. In Immunobiology: The Immune System in Health and Disease, pp 382-388, New York: Garland Publishing.

Kamiyama S, Teruya Y, Nohra M \& Kanazawa MD 2004 Impact of detection of bacterial endotoxin in menstrual effluent on the pregnancy rate in in vitro fertilization and embryo transfer. Fertility and Sterility $\mathbf{8 4}$ 788-792.

Karsch FJ, Battaglia DF, Breen KM, Debus N \& Harris TG 2002 Mechanisms for ovarian cycle disruption by immune/inflammatory stress. Stress $\mathbf{5}$ 101-112.

Ma X, Dong Y, Matzuk MM \& Kumar TR 2004 Targeted disruption of luteinizing hormone beta-subunit leads to hypogonadism, defects in gonadal steroidogenesis, and infertility. PNAS 101 17294-17299.

Machelon V \& Emilie D 1997 Production of ovarian cytokines and their role in ovulation in the mammalian ovary. European Cytokine Network 8 137-143.
Mateus L, Lopes da Costa L, Diniz P \& Ziecik AJ 2003 Relationship between endotoxin and prostaglandin (PGE2 and PGFM) concentrations and ovarian function in dairy cows with puerperal endometritis. Animal Reproduction Science 76 143-154.

Matzuk MM, Burns KH, Viveiros MM \& Eppig J 2002 Intercellular communication in the mammalian ovary: oocytes carry the conversation. Science $2962178-2180$.

Moenter SM, Caraty A \& Karsch FJ 1990 The estradiol-induced surge of gonadotropin-releasing hormone in the ewe. Endocrinology 127 1375-1384.

Moussavi AR, Gilbert RO, Overton TR, Bauman DE \& Butler WR 2007 Effects of feeding fish meal and n-3 fatty acids on ovarian and uterine responses in early lactating dairy cows. Journal of Dairy Science $\mathbf{9 0}$ 145-154.

Perry GA, Smith MF, Lucy MC, Green JA, Parks TE, MacNeil MD, Roberts AJ \& Geary TW 2005 Relationship between follicle size at insemination and pregnancy success. PNAS 102 5268-5273.

Petrovska M, Dimitrov DG \& Michael SD 1996 Quantitative changes in macrophage distribution in normal mouse ovary over the course of the estrous cycle examined with an image analysis system. American Journal of Reproductive Immunology 36 175-183.

Poltorak A, He X, Smirnova I, Liu MY, Van Huffel C, Du X, Birdwell D, Alejos E, Silva M, Galanos C et al. 1998 Defective LPS signaling in $\mathrm{C} 3 \mathrm{H} / \mathrm{HeJ}$ and $\mathrm{C} 57 \mathrm{BL} / 10 \mathrm{ScCr}$ mice: mutations in T/r4 gene. Science $\mathbf{2 8 2}$ 2085-2088.

Quayle AJ 2002 The innate and early immune response to pathogen challenge in the female genital tract and the pivotal role of epithelial cells. Journal of Reproductive Immunology 57 61-79.

Richards JS 1994 Hormonal control of gene expression in the ovary. Endocrine Reviews 15 725-751.

Robinson RS, Hammond AJ, Hunter MG \& Mann GE 2005 The induction of a delayed post-ovulatory progesterone rise in dairy cows: a novel model. Domestic Animal Endocrinology 28 285-295.

Rodgers RJ, Lavranos TC, van Wezel IL \& Irving-Rodgers HF 1999 Development of the ovarian follicular epithelium. Molecular and Cellular Endocrinology 151 171-179.

Schams D \& Berisha B 2002 Steroids as local regulators of ovarian activity in domestic animals. Domestic Animal Endocrinology 23 53-65.

Sheldon IM \& Dobson H 2004 Postpartum uterine health in cattle. Animal Reproduction Science 82-83 295-306.

Sheldon IM, Noakes DE, Rycroft AN, Pfeiffer DU \& Dobson H 2002 Influence of uterine bacterial contamination after parturition on ovarian dominant follicle selection and follicle growth and function in cattle. Reproduction 123 837-845.

Shell SA, Hesse C, Morris SM Jr \& Milcarek C 2005 Elevated levels of the 64-kDa cleavage stimulatory factor (CstF-64) in lipopolysaccharidestimulated macrophages influence gene expression and induce alternative poly $(\mathrm{A})$ site selection. Journal of Biological Chemistry 280 39950-39961.

Shimada M, Hernandez-Gonzalez I, Gonzalez-Robanya I \& Richards JS 2006 Induced expression of pattern recognition receptors (PRRs) in cumulus oocyte complexes (COCs): Novel evidence for innate immune-like functions during ovulation. Molecular Endocrinology $203228-3239$.

Singh BN, Lucas JJ, Hayes GR, Kumar I, Beach DH, Frajblat M, Gilbert RO, Sommer U \& Costello CE 2004 Tritrichomonas foetus induces apoptotic cell death in bovine vaginal epithelial cells. Infection and Immunity 72 4151-4158.

Spencer TE, Johnson GA, Burghardt RC \& Bazer FW 2004 Progesterone and placental hormone actions on the uterus: insights from domestic animals. Biology of Reproduction 71 2-10.

Spicer LJ \& Alpizar E 1994 Effects of cytokines on FSH-induced estradiol production by bovine granulosa cells in vitro: dependence on size of follicle. Domestic Animal Endocrinology 11 25-34.

Suzuki C, Yoshioka K, Iwamura S \& Hirose H 2001 Endotoxin induces delayed ovulation following endocrine aberration during the proestrous phase in Holstein heifers. Domestic Animal Endocrinology 20 267-278.

Taylor CC \& Terranova PF 1995 Lipopolysaccharide inhibits rat ovarian thecal-interstitial cell steroid secretion in vitro. Endocrinology 136 5527-5532.

Taylor CC \& Terranova PF 1996 Lipopolysaccharide inhibits in vitro luteinizing hormone-stimulated rat ovarian granulosa cell estradiol but not progesterone secretion. Biology of Reproduction 54 1390-1396. 
Tsatsanis C, Androulidaki A, Alissafi T, Charalampopoulos I, Dermitzaki E, Roger T, Gravanis A \& Margioris AN 2006 Corticotropin-releasing factor and the urocortins induce the expression of TLR4 in macrophages via activation of the transcription factors PU.1 and AP-1. Journal of Immunology 176 1869-1877.

Williams E, Fischer D, Noakes D, England G, Rycroft A, Dobson H \& Sheldon I 2007 The relationship between uterine pathogen growth density and ovarian function in the postpartum dairy cow. Theriogenology 68 549-559.

Xiao E, Xia-Zhang L, Barth A, Zhu J \& Ferin M 1998 Stress and the menstrual cycle: relevance of cycle quality in the short- and long-term response to a 5-day endotoxin challenge during the follicular phase in the rhesus monkey. Journal of Clinical Endocrinology and Metabolism 83 2454-2460.
Xu Z, Garverick HA, Smith GW, Smith MF, Hamilton SA \& Youngquist RS 1995 Expression of messenger ribonucleic acid encoding cytochrome P450 side-chain cleavage, cytochrome p450 17 alpha-hydroxylase, and cytochrome P450 aromatase in bovine follicles during the first follicular wave. Endocrinology 136 981-989.

Received 15 May 2007

First decision 19 June 2007

Revised manuscript received 24 July 2007

Accepted 8 August 2007 